\title{
MTA SZTAKI DSD - 25 éve a digitális könyvtárak szolgálatában
}

\author{
Kovács László, Micsik András \\ MTA SZTAKI Elosztott Rendszerek Osztály \\ laszlo.kovacs@sztaki.mta.hu, andras.micsik@sztaki.mta.hu
}

\section{Bevezetés}

25 évvel ezelőtt, 1994. január 1-én alapítottuk meg az MTA SZTAKI DSD, Elosztott Rendszerek Osztályt (dsd.sztaki.hu). Az osztály kezdetben, azakkori Magyarországon még újdonságnak számító World Wide Webes technológiák hazai bevezetésében, elterjesztésében volt úttörő. Az ország első webszolgáltatásai (pl. SZTAKI Szótár), kormányzati honlapjai (www.kormany.hu, www.kancellaria.gov.hu), webes müalkotásai (pl. Nightwatch, SZTAKI Gallery) létrehozása mellett gyorsan kialakult az a tematikus profil, mely azóta is töretlenül jellemzi az osztály kutatás-fejlesztési tevékenységét. Ebben a szakmai profilban az (elosztott) digitális könyvtári és archivum rendszerek kutatás-fejlesztése kiemelkedő és meghatározó szerephez jutott és jut a mai napig is, a digitális könyvtárak az MTA SZTAKI DSD osztály alapvető, szakmai identitásképző témaköre.

A 25 év során elért szakmai eredményeinket áttekintve, néhány jelentősebb, a témakörbe esö projektet mutatunk be, konkrét szakmai feladatok köré csoportosítva azokat.

\section{A keresés aspektusai}

A digitális könyvtárak a World Wide Web elterjedésének egészen korai szakaszában megjelentek (sőt, voltak FTP és Gopher alapú digitális könyvtárak is, de ki emlékszik már rájuk?). Akkoriban azonban még nem voltak univerzális webes keresök (lásd Google), és így a több helyen egyszerre történő, elosztott keresés igénye hamar felmerült. A számítástechnika és számitógéptudomány diszciplinán belül az első digitális könyvtár az USA-ban épült meg és az NCSTRL ${ }^{1}$ (Networked Computer Science Technical Report Library) nevet kapta. Az NCSTRL elosztott rendszerként egymáshoz kapcsolt könyvtári csomópontok hálózata volt, melyben egy elosztott keresési algoritmus alapján lehetett megtalálni a keresett digitális objektumokat (kutatási jelentéseket, tudományos cikkeket, publikációkat). A DSD osztály megalakulásával szinte egyidejüleg még 1995-ben felállitottuk az MTA SZTAKI-ban az NCSTRL első európai csomópontját és bekapcsoltuk az NCSTRL hálózatba. A rendszer az elosztott és központi keresési módszereket kombinálta, és sok azóta alapvetőnek tartott szolgáltatást vezetett be, mint például egységes API, perzisztens linkek stb. és a hamarosan megjelenö OAI-PMH protokoll is sokban hasonlit erre a korai API-ra.

A digitális könyvtári kutatási területen Európa jelentősen elmaradt az USA mögött, amit az Unió a DELOS LTR (Long Term Research) ESPRIT projekt indításával igyekezett behozni. A DELOS LTR projekt alapkutatási projektként meghatározó szerepet játszott abban, hogy Európában létrejött a digitális könyvtári 
szakmai témakörrel foglalkozó kutatók és fejlesztök nemzetközi közössége, és megteremtődött az európai digitális könyvtári kutatások humán erőforrás alapja, egyben akkor jelentős pénzügyi forrásokat, támogatást is kapott e szakmai terület. Az MTA SZTAKI DSD a kezdet kezdetén történő részvétele a DELOS LTR projektben tette lehetővé azt, hogy elkezdődjön Magyarországon is a digitális archivumok kutatása és fejlesztése, immáron harmonikusan beágyazva az európai digitális könyvtári K+F eröfeszitésekbe. Késöbb az MTA SZTAKI DSD folyamatosan jelen volt az európai digitális könyvtári kutatói közösségben a DELOS NoE, illetve a DELOS NoE2 európai (FP4 és FP5) projektek tagjaként és számos más hazai és nemzetközi $\mathrm{K}+\mathrm{F}$ projektben kamatoztathatta az európai szinten kifejlesztett, illetve az ott elsajátított technológiákat, müszaki megoldásokat.

Az MTA SZTAKI az ERCIM (European Research Consortium for Informatics and Mathematics) konzorciumba való belépése után jelentős szerepet kapott az ERCIM saját elosztott digitális könyvtári rendszerének létrehozási folyamatában. Elkészült az ETRDL ${ }^{2}$ (ERCIM Technical Reference Digital Library), melyben az MTA SZTAKI hazai csomópontot üzemeltetett és az ETRDL (Európa) - NCSTRL (USA) kapcsolat létrehozásáért volt felelős. Később az ETRDL technikai alapjain készitettük az AQUA keresőnket, amely korai Java applet technológiával az ismétléses finomítás (iterative refinement via facets) keresési módszert támogatta ${ }^{3}$.

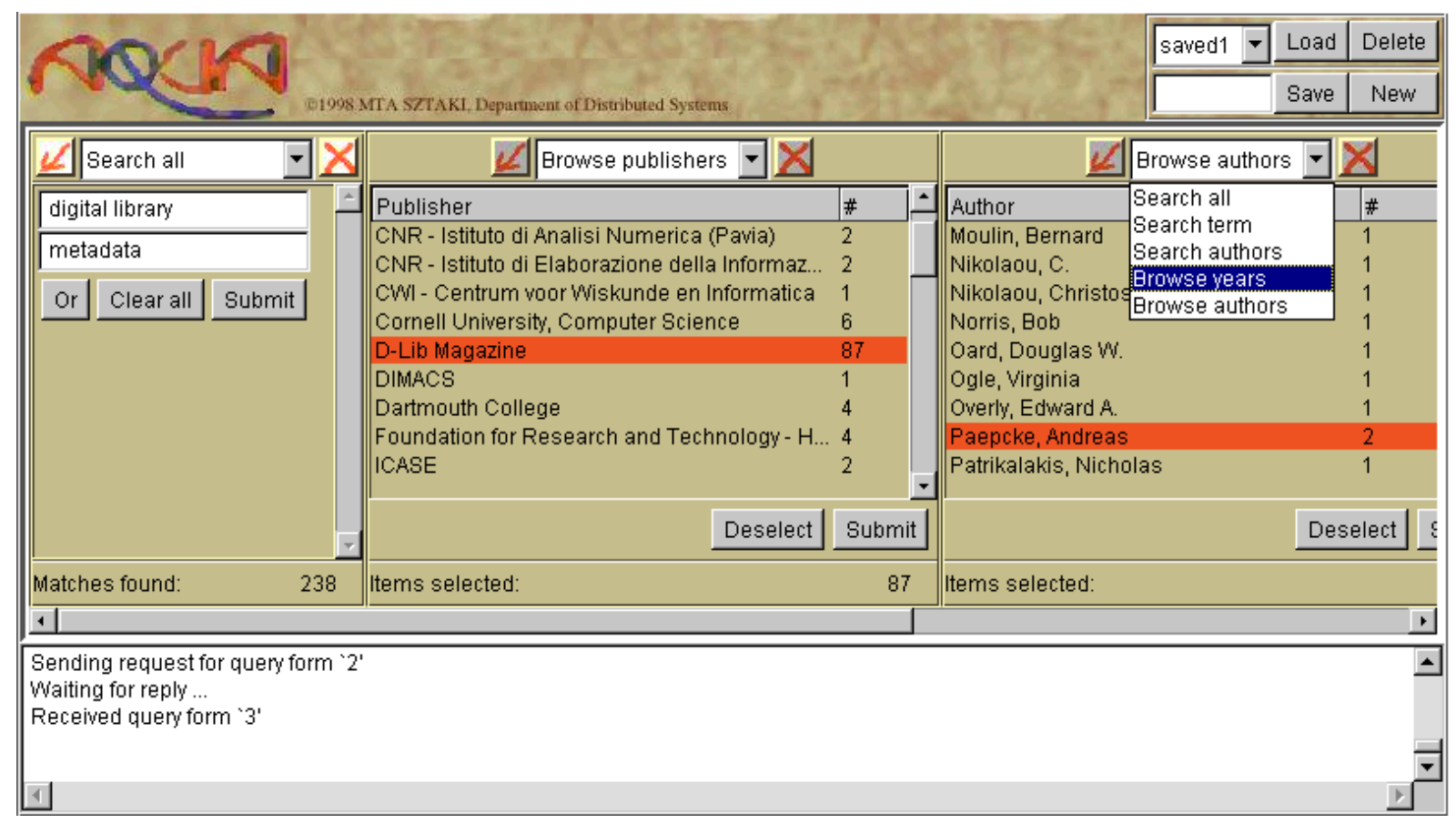

1. ábra: Az AQUA keresöfelület 1998-ból

\footnotetext{
2 A. Andreoni et al: The ERCIM Technical Reference Digital Library. D-Lib Magazine December 1999

3 L. Kovács, A. Micsik, B. Pataki: AQUA: query visualization for the NCSTRL digital library. Proceedings of the fourth ACM conference on digital libraries. Berkeley, 1999.
} 
A nagy keresömotorok hatására a központositott keresöszolgáltatások váltak népszerüvé, mivel gyorsabbak és megbízhatóbbak voltak elosztott társaiknál. Ezek elterjedését roppant mód felgyorsitotta az OAI-PMH protokoll, melyet elöször a magyar OSZK-SZTAKI Hektár ${ }^{4}$ projekten belül próbáltunk az OSZK MEK-kel együtt itthon népszerüsíteni. A Hektár projektben kialakitott kereső megoldás az általunk kifejlesztett NDA@SZTAKI digitális könyvtári rendszer felületen is megjelent, mely az időközben hasonló elvek mentén megvalósult Nemzeti Digitális Adattár alternatív keresöfelülete volt. Ez a szolgáltatásunk jelenleg az OAI kereső 5 nevü reinkarnációjában él tovább, és a nyiltt teljes szövegü repozitóriumok és folyóiratok közös, országos keresőfelületét nyújtja.

Továbbra is foglalkoztatott minket azonban az elosztott digitális könyvtárak és archívumhálózatok problémaköre, és a kis- és közösségi rádiózás szükségleteinek megfelelő peer-to-peer elosztott rádióarchívum-hálózatot fejlesztettünk ki a StreamOnTheFly EU projektben ${ }^{6}$. Itt a csomópontok meghatározhatták nyelvi, regionális, vagy bármely más alapon, hogy mely más csomópontokkal cserélnek metaadatokat.

A StreamOnTheFly európai hálózat több mint 10 éven keresztül üzemelt megbizhatóan és biztositotta az európai közösségi rádiócsatornák archiválási igényeit, illetve a csatornák közötti müsorcserét, mintegy virtuális, ingyenes piacteret hozva létre a multimédia (leginkább audió) tartalmak kicserélésére és újrafelhasználására. A kis- és közösségi rádiócsatornák ugyanis mindig is eröforráshiánnyal küzdöttek, ezért a StreamOnTheFly hálózat jelentősen hozzájárult e csatornák mindennapi takarékos müködéséhez, fennmaradásához.

A StreamOnTheFly hálózat felbomlása után több mint 10 évvel digitális "maradványként" a radio.sztaki.hu oldalon ma is belehallgathatunk magyar városi rádiók korábban archivált müsoraiba.

A nem szöveges média formátumok (audió, kép, videó stb.) terjedésével az ezekben való keresés lett az aktuális probléma. Az MTA SZTAKI CrossMedia projektünkben a képi információk és metaadatok (szemantikus) keresésének kombinálási lehetőségeivel kisérleteztünk ${ }^{8}$.

Végső soron a plágiumkeresés is egy ilyen újfajta keresési technika, amely sokféle dokumentumformátumból kivonja a szöveget, és észleli az egyező szövegrészeket a különböző dokumentumokban. Az MTA SZTAKI KOPI9 plágiumkeresőjét 2004-ben

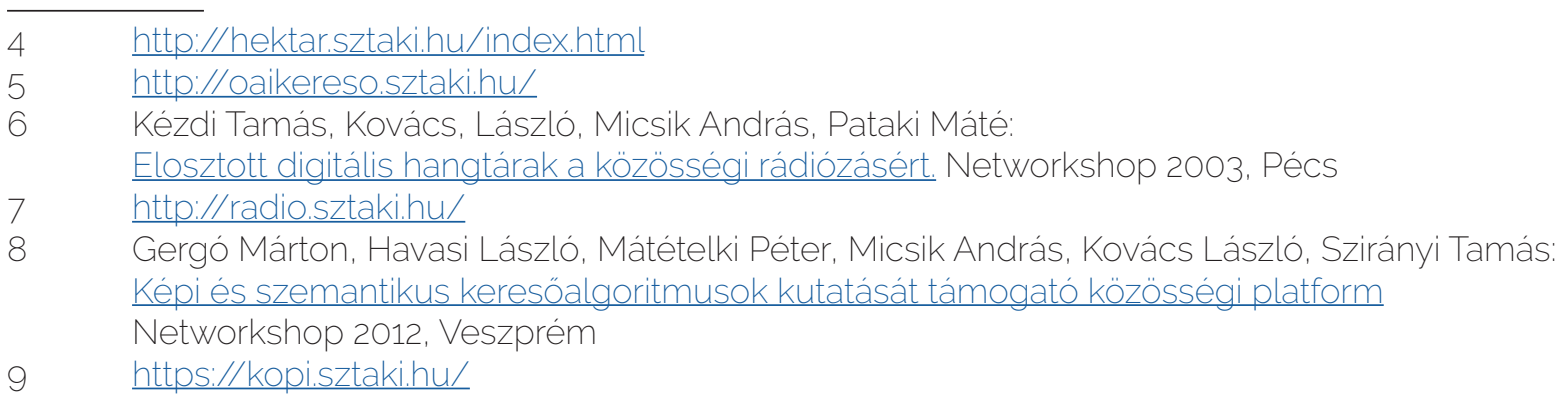


hoztuk létre, és azóta üzemeltetjük. Ez volt az első plágiumkereső Magyarországon, amely jól kezelte a magyar nyelvü szövegeket, és késöbb 2011-ben, a világon elsőként, valósitott meg jó minőségü forditási plágiumkeresést ${ }^{10}$ is, amely például detektálni tudta, ha valaki a dolgozatába az angol nyelvü Wikipedia-ból magyarra forditott szövegrészeket illesztett be.

\section{Metaadatok, dokumentumok, kapcsolt adatok}

Az 1998-ban megjelent Dublin Core (DC) metaadatleíró rendszer forradalmasította a metaadatok világát. A Dublin Core megnyitotta az utat az eddig egymástól elkülönülve fejlődő leíró rendszerek (mint például a MARC), átjárhatóvá, egymásra leképezhetővé tételére, meghatározva a leglényegesebb, esszenciális metaadatok legszükebb körét. Kezdetben úgy képzelték, hogy az egyes szakágak (pl. kereskedelem, könyvtárak, közigazgatás stb.) mind kialakitják a DC, majd késöbb qDC alapú, de specializált változataikat, az ún. alkalmazási profilokat (application profile). Ezekszabványositására, áttekintéséreés kényelmes, grafikus szerkesztésére szolgált az azonos nevü EU projekt keretében létrehozott CORES rendszer, melynek fejlesztésében segédkeztünk, és melyet sokáig üzemeltettünk ${ }^{11}$.

Az alkalmazási profilok szakmai körökben történö lassú terjedésével egyidejüleg megjelent egy alapvetöbb - persze bonyolultabb - koncepció, a Szemantikus Web, amellyel egyszerü metaadatrekordokat, tezauruszokat és logikai modelleket (ontológiákat) egyaránt le lehetett írni. A cél tehát az lett, hogy minden területen létrejöjjön a tudásreprezentációhoz szükséges ontológiák megfelelő halmaza. A Szemantikus Web késöbb egyszerübb és hatékonyabb formában kapcsolt adatok (linked data (LD), linked open data (LOD)) néven indult rohamos fejlödésnek.

A kapcsolt adatokat a már korábban emlitett CrossMedia projektben használtuk szemantikus keresésre, vagyis konkrét szóelőfordulások helyett egy tezaurusz részgráfja alapján kerestünk (pl. szinonimák, hiponimák bevonásával) megfelelő képeket.

2011-ben elindult a lod.sztaki.hu szolgáltatás az Intézetben, amely az OAI alapon összegyüjtött hazai kulturális adatokból előállitott kapcsolt adathalmaz szolgáltatás, és több mint 11 millió egyszerü tényböl (RDF triple) áll össze.

Végül 2016-ban, a COURAGE EU projekt indulásával sikerült egy a kezdetektöl és alapjaiban is kapcsolt adatos (RDF alapú) adattár-megoldást létrehoznunk.

Teljes rendszerek fejlesztése és üzemeltetése

A fejlesztések mellett mindig is szerettük, ha a szoftvereink müködnek és széles körben használják is azokat. Ezért fokozott gondot forditottunk az üzemeltetésre és a folyamatos fenntartásra, támogatásra. Néhány komplexebb rendszert kiemelnénk a létrehozott szolgáltatás-portfóliónkból.

\footnotetext{
10 Pataki Máté: Plágiumkeresés különbözö nyelvek között. Networkshop 2011, Kaposvár

11 Fülöp Csaba, Kovács László, Micsik, András

Metaadatsémák nyilvántartása szemantikus web alapon. Networkshop 2004, Györ
} 
A már emlitett StreamOnTheFly európai rádióarchivum rendszer több csomópontból álló, elosztott rendszervolt, ahol az egyes csomópontok dönthettek arról, hogy mely más csomópontokkal lépnek partnerségre. Egy csomóponton belül több "rádióadó" archiválhatta müsorait, a szerkesztői jogok szabályozásával akár sorozatonként más-más ember végezhette kényelmesen a hanganyagok, metaadatok feltöltését és/vagy szerkesztését. A felhasználók pedig saját, akár több órás egyéniesitett (perszonalizált) rádiómüsort állithattak össze az archivumból és stream formájában élvezhették azt.

A KOPI plágiumkereső is összetett osztott rendszer, mivel a keresés összetett belső folyamatának lépéseit különböző célszerverek végzik. A SZTAKI Szótár is ide kivánkozik, bár az csak szavak archivuma, de napi 80-100 ezer látogatót szolgál ki 8-10 szerver preciz együttmüködésével. A szótár tartalmak tárolását pedig egy gráfadatbázis (neouj) szolgálja ki. A SZTAKI Szótár kapcsán érdemes megjegyeznünk, hogy itt gondosan ügyeltünk a szótári kereső URL-ek hosszútávú megörzésére. Ezért, ha valaki 1995-ben a szótár indulásakor berakott egy linket (keresést) egy szóra a honlapjára, ha erre ma 2019-ben ráklikkelnek, akkor a szótár ma is megadja a megfelelő forditást.

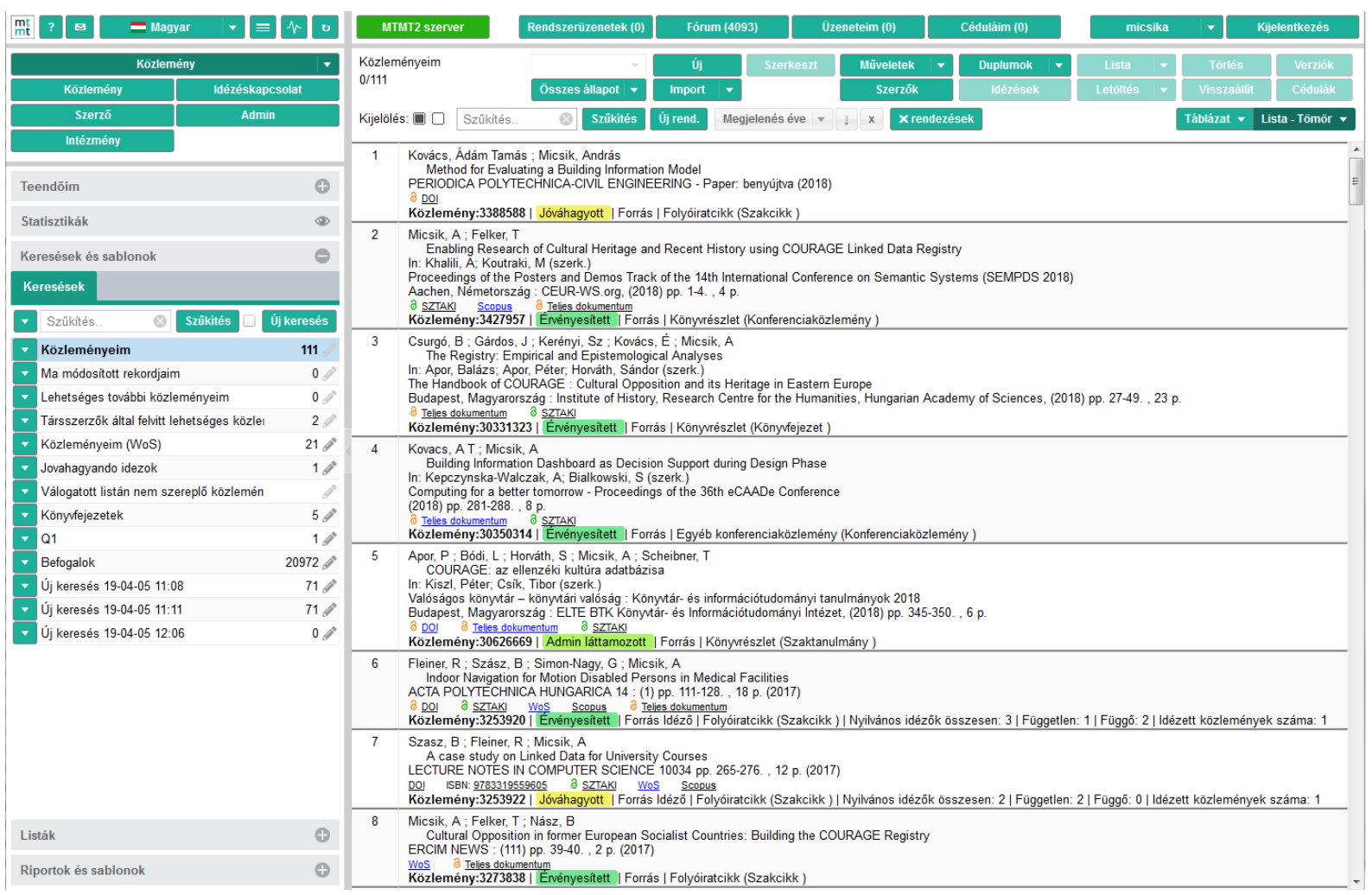

2. ábra: Az MTMT2 szerkesztői felülete 
AzMTASZTAKIElosztott Rendszerek osztályán fejlesztettük kia MagyarTudományos Müvek Tára 2018. novembere óta éles üzemelésü 2-es (MTMT2) szoftververzióját ${ }^{12}$. Ez volt pályafutásunk során eddig a legbonyolultabb és legnagyobb saját fejlesztésü szoftver-rendszer. Az MTMT2 a külvilággal egy REST API-n keresztül kommunikál, ezt használja a teljesen új nyilvános felület, amelyen bejelentkezés nélkül akár mobilon is lehet böngészni a szerzök, csoportok munkásságát, vagy az egyes témakörökben megjelent cikkeket. A szerkesztöi felület ún. egyablakos Javascript alkalmazás, amely egy teljes professzionális munkakörnyezetet (workspace) ad a közlemények felviteli, kiegészitési stb. teljes körü adatkurátori feladatainak elvégzésére. Az MTMT2 rendszert több mint 60.000 felhasználó, az ország teljes kutatói szférája használja rendszeresen.

Végezetül a COURAGE ${ }^{13}$ EU projekt keretében az általunk létrehozott digitális archivum rendszerét említjük meg, amely a technikai fejlettségével emelkedik ki. Az adatokat RDF triple store tárolja a külön e célra készült COURAGE ontológia, mint adatséma alapján. A felhasználói felület nagy részét is kapcsolt adat konfiguráció, illetve SPARQL lekérdezések vezérlik. Az adatfelvitel során egyböl létrejönnek a kétirányú adatkapcsolatok, relációk, melyek mentén a létrehozott szemantikus tudásgráf sokoldalúan böngészhetö. A rendszergazda pedig menet közben a rendszer leállása nélkül fel tud venni új adatmezöket, vagy meg tudja változtatni a meglévőket (séma módosítás), azok megjelenési módját is beleértve.
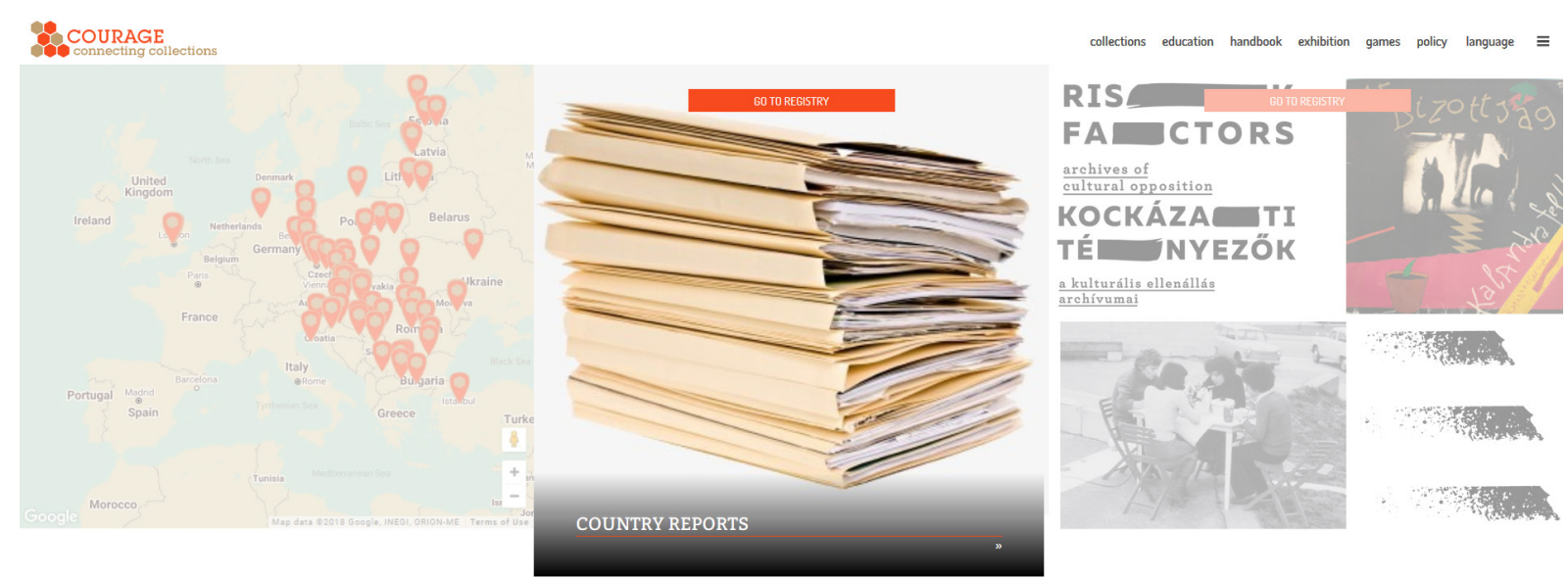

Connecting collections

Cultural Opposition - Understanding the Cultural Heritage of Dissent in the Former Socialist Countries

3. ábra: A COURAGE projekt honlapja

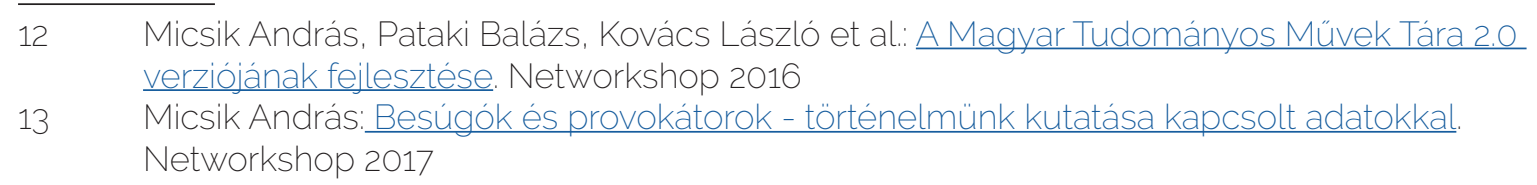


Utószó

AzMTASZTAKIDSD, a kutatóintézet Elosztott Rendszerek Osztálya 25éven keresztül töretlenül dolgozott a digitális könyvtárak és archivumok kutatás-fejlesztése területén és létrehozott egy egyedülálló tudás és technológiai megoldás portfoliót, mely jelenleg a teljes magyar felhasználói közösség szolgálatára áll. A jövöben szeretnénk tovább foglalkoznia tudásreprezentáció és tudásfúzió felmerülő elméleti és gyakorlati problémáival. A portfolióban nem csupán korábbi megoldásaink, illetve az elsajátított technológiák, know-how-k stb. reprezentálnak értéket, hanem az az időközben az osztályon kialakitott képességünk, mely bonyolult müszakitudományos problémák kezelését holisztikusan szemlélve egyidejüleg képes akár felfedezö, alkalmazott kutatási és fejlesztési tevékenységeket kombináltan végezni. Az osztály munkatársai e képesség birtokában bátran vállalkoznak bármely új kihivás esetén egy lehetséges, a gyakorlatban müködő, korszerü és tudományosan is értékelhető megoldást megtalálni. 